4. Мартинова І. М. Упровадження інноваційних педагогічних технологій як засіб розвитку творчого потенціалу педагога/ І. М. Мартинова // Нова педагогічна думка - 2016 - № 4 (88) - С. 18-22.

5. Педагогічні технології у неперервній професійній освіті : монографія / С. О. Сисоєва та ін. ; за ред. С. О. Сисоєвої. - К. : ВІПОЛ, 2001.

6. Чубко О. П. Інноваційні технології навчання в контексті педагогічної підготовки майбутнього вчителя / О. П. Чубко // Вісн. Чернігів. нац. пед. ун-ту. Педагогічні науки. - 2013. - Вип. 108/1. - Режим доступу: http://nbuv.gov.ua/UJRN/VchdpuP $2013 \quad 110837$.

References

1. Dychkivs'ka I. M. Innovatsiyni pedahohichni tekhnolohiyi: pidruchnyk / I. M. Dychkivs'ka. - 2-he vyd., dopovn. - K. : Akademvydav,2012.
2. Zakon Pro priorytetni napryamy innovatsiynoyi diyal'nosti v Ukrayini vid 08.09.2011 № 3715-VI (Redaktsiya stanom na 05.12.2012).

3. Entsyklopediya pedahohichnykh tekhnolohiy ta innovatsiy / avtorukladach N. P. Navolokova. - KH. : VH "Osnova", 2009.

4. Martynova I. M. Uprovadzhennya innovatsiynykh pedahohichnykh tekhnolohiy yak zasib rozvytku tvorchoho potentsialu pedahoha I. M. Martynova// Nova pedahohichna dumka. - 2016. - № 4 (88). - S. 18-22.

5. Pedahohichni tekhnolohiyi u neperervniy profesiyniy osviti : Monohrafiya I S. O. Sysoyeva et al / za red. S. O. Sysoyevoyi. - K. V1P0L, 2001.

6. Chubko O. P. Innovatsiyni tekhnolohiyi navchannya v konteksti pedahohichnoyi pidhotovky maybutn'oho vchytelya / O.P. Chubko // Visnyk Chernihivs'koho natsional'noho pedahohichnoho universytetu. Pedahohichni nauky. - 2013. - Vyp. 108.1. - Rezhym dostupu: http://nbuv.gov.ua/UJRN/VchdpuP 2013110837.

Надійшла до редколегії 24.11.19

N. Holovko, Ph.D, Associate Professor;

V. Zarutska, Master's student, Educational program Higher School Pedagogy;

A. Cherepakha, Master's student, Educational program Higher School Pedagogy

Taras Shevchenko National University of Kyiv, Kyiv, Ukraine

\title{
INNOVATIVE PEDAGOGICAL TECHNOLOGIES AS A METHOD OF ACTIVATING THE COGNITIVE ACTIVITY OF STUDENTS IN PROFESSIONAL TRAINING
}

Different approaches to the interpretation of the essence of innovative pedagogical technologies have been highlighted in the article, as well as their influence on the activation of cognitive activity of students as future specialists. It has been analysed that methods of intensification of educational activities are aimed at forming positive motives for learning, stimulate cognitive activity and at the same time contribute to the enrichment of educational information. The implementing of innovative pedagogical technologies in the educational process will increase students' interest in learning, teach them to work independently, be communicative and mobile, adapt to the requirements of modern society. It has been considered that innovative pedagogical technologies are the purposeful, systematic and consistent implementation of innovative methods, techniques, tools that encompass a holistic educational process from determining its purpose to expected results. This is due to the fact that the training system of a future specialist must comply with modern trends in the development of society, its needs.

Innovative learning is a learning and educational activity focused on dynamic changes in the world around us, based on the development of various forms of thinking, creative abilities, and high social and adaptive abilities of an individual.

In the professional and practical training of future teachers, technologies are being introduced to form their professional competence, among which are: personality-oriented education and training, group educational technology, information technology, project training, problem-based learning theory, interactive technology, creative personality formation technology, game technology theory, specialized training, integrated technologies and others.

Technologies contribute to the assimilation of knowledge and skills, the activation and development of mental actions, the system of effective practical sphere, the strengthening of emotionality, the development of a creative nature; independence in decision making; the desire to acquire skills in a relatively short period.

Keywords: innovative pedagogical technologies, activation of cognitive activity, professional training, educational process.

УДК 371.134: 3.16.2.00176

DOI: https://doi.org/10.17721/2415-3699.2020.12.03

О. Деркач, асп.

Київський національний університет імені Тараса Шевченка, Київ

\section{ЯКІСТЬ ВИЩОї ОСВІТИ ПОЛЬЩІ У ПРОЦЕСІ ТРАНСФОРМАЦІї ОСВІТНЬОї ПОЛІТИКИ}

Проаналізовано системні зміни в закладах вищої освіти Польщі за останні два десятиліття. Класична ідея стихійного суспільного розвитку та гіпотеза взаємодії формальних і неформальних закладів, яка розроблена на основі нової інституціональної освітньої політики, була прийнята як методологічна основа для аналізу й оцінки трансформації польської вищої освіти. Трансформації в польській вищій освіті є частиною більш загальних змін ролі університетів - змін, які можуть обмежити незалежність досліджень і зробити його інструментом домінуючих суспільних, політичних та економічних сил. Проаналізовано діяльність Державної акредитаційної комісії Польщі, висвітлено основні їі компетенції.

Ключові слова: вища освіта, якість освіти, трансформація, фінансування, Державна акредитаційна комісія.

Постановка проблеми. У процесі трансформації польської вищої освіти можна виділити два етапи. На першому етапі головним фактором змін став закон "Про вищу освіту" [1] від 12 вересня 1990 р., що дозволяє розвивати приватний сектор вищої освіти.

Основними досягненнями Закону 1990 р. стали: децентралізація управління вищою освітою, ліквідація державної монополії на вищу освіту й автономія ЗВО, диверсифікація системи вищої освіти - поява приватних закладів вищої освіти, виборність ректорів, свобода у визначенні навчальних програм, майнові права і свободи (університет може розпоряджатися об'єктами, що має у власності), суттєві зміни в бюджетуванні та фрінансуванні наукових досліджень, запровадження принципу конкурентності у здобутті дослідницьких грантів тощо. Варто зазначити, що громадськість отримала право й засіб контролю планів і рішень міністра, відповідального за науку та вищу освіту.

Процеси, що відбуваються на другому етапі, $є$ наслідком нового законодавства, яке впроваджує принципи Болонської програми до польської вищої освіти, а фінансове становище університету змінюється через демографрічний спад в країні. Із початку освітньої трансформації спостерігалася помітна тенденція до просування вищої освіти з дотриманням конституційного принципу безкоштовного навчання, але без значного збільшення державних витрат. Мета була досягнута завдяки розвитку приватного сектору й комерціалізації значної частини діяльності державного сектору. Труднощі та конфрлікти виявились, коли падіння попиту на послуги університету обмежувало приплив приватних коштів як до приватних, так і до державних університетів. Посилення конкуренції для студентів збіглося із впровадженням систем, спрямованих на забезпечення якості освіти. Фінансові обмеження, зростаюча конкуренція за кошти, що надходять від студентів, і система оцінювання науково-педагогічних працівників - усе це означає, що основним фокусом уваги людей та організацій, що беруть участь у навчальному процесі, $€$ формулювання університетських освітніх принципів відповідно до керівних принципів Міністерства, а потім здатність довести, що ці принципи реалізовані. 
Часті зміни правил функціонування, особливо у сфері освіти, означають, що незважаючи на задекларований принцип автономії, університети постійно поглинаються роботою над впровадженням подальших бюрократичних нововведень. Формальний характер цієї інноваційної діяльності й нерозуміння ії̈ сенсу великою частиною академічної спільноти призводить до того, що схематизм і очевидна систематизація замінили дискусії й дії щодо адаптації моделі та освітніх програм до надзвичайно швидких технологічних, політичних і моральних змін, що відбуваються у світі.

Аналіз останніх досліджень і публікацій. Проблеми вищої освіти Польщі, у тому числі якість освіти та іï фрінансове забезпечення, широко представлені у працях таких вітчизняних і зарубіжних науковців: А. Василюк, А. Боголіб, Т. Іванова, С. Касьянова, І. Ковчина, К. Корсак, К. Павловський, Р. Пахоцінський, О. Робак, А. Розмус, Т. Фінніков, В. Щербаченко, К. Хиц, Н. Яковець тощо. Однак в умовах соціально-економічних змін і постійного вдосконалення галузі вищої освіти відчувається, що це питання є недостатньо дослідженим, що потребує подальших наукових розробок у галузі фінансування вищої освіти в Польщі.

Мета статті - привернути увагу до зв'язків між методом фрінансування вищої освіти у Польщі, а також якістю освіти та сигналізувати про необхідність підтримання більшої рівноваги у взаємозв'язку між традиційною роллю університету й тенденцією підпорядковувати його чинним ринковим силам.

Завдання: виявити актуальні ідеї щодо якості освіти Польщі у процесі трансформації освітньої політики; визначити в чому полягає сутність поняття "якість освіти".

Викладення основного матеріалу. Якість освіти в Польщі стала предметом особливої уваги з двох основних причин. Перша причина - досить поширене відчуття, того що якість навчального процесу, так і якість його результатів значно знизилися, оскільки кількість коледжів та університетів зростала. Друга причина - реформа навчальних закладів і процесу навчання у зв'язку з приєднанням Польщі до Європейського Союзу й участі в Болонському процесі.

Якість освіти - це узагальнений показник розвитку суспільства в певному часовому вимірі. Тому його варто розглядати в динаміці тих змін, що характеризують поступ держави в контексті світових тенденцій: вона рухається до консолідації й інтеграції у світову спільноту чи протистоїть їй, ставлячи власні інтереси понад усе.

У процесі дослідження встановлено, що особистісне спрямування освіти зумовлює потребу інтегровано оцінювати якість освіти у єдності індивідуальних характеристик особистості, педагогічних показників організації освітнього середовища та соціальних параметрів функціонування освітніх систем. Із нашого погляду, доцільно вирізняти внутрішні й зовнішні чинники якості вищої освіти, які характеризують освітній процес, його результат і систему освіти загалом. Зокрема, внутрішні характеристики якості вищої освіти такі: якість освітнього середовища ("технологічність" управління освітнім процесом, ефективність науково-методичної роботи, ресурсне забезпечення навчального процесу, кадровий потенціал закладу тощо); реалізації освітнього процесу (науковість і доступність змісту вищої освіти, педагогічну майстерність викладача, ефективність засобів навчання, зокрема якість навчальних посібників, задоволення різноманітних освітніх потреб тощо); результатів освітнього процесу (рівень навчальних досягнень студентів (абітурієнтів), розвиток їхнього мислення, ступінь соціальної адаптації, культури й вихованості студентів тощо). Зовнішні показники якості вищої освіти характеризують їі як соціальну інституцію, яка відбиває ефективність фрункціонування освітньої системи, її вплив на систему освіти загалом. Це - доступність до якісної вищої освіти всіх громадян незалежно від їхнього соціального й майнового статусів чи інших обмежень, її відповідність освітнім стандартам, задоволення освітніх запитів, можливості у виборі робочого міста, відкриття перспектив професійного росту та соціального статусу тощо.

Зазвичай ми намагаємося визначити якість освіти, посилаючись на весь навчальний процес і навчальні цілі. Отже, визначення цілей навчання є ключовим фрактором для оцінки якості освіти.

На основі наук про управління процесом навчанням, управління якістю освіти, зазвичай, аналізується 3 погляду так званих внутрішніх і зовнішніх зацікавлених сторін, з акцентом на цілі зовнішніх зацікавлених сторін. Натепер досвід показує, що такий погляд призводить до необґрунтованого зниження ролі академічного персоналу та до викриття навчальних цілей, важливих із погляду нинішньої політики, але не завжди вони служать довготерміновому сталому розвитку. Кращу основу для визначення якості освіти забезпечують цілі навчання, сформульовані в 1991 р. У Доповіді Римського клубу "Перша глобальна революція" та підході, запропонованому в Доповіді Делора [2], де зазначено, що сучасна освіта повинна включати чотири основні групи цілей:

- навчитися жити в гармонії, взаємодіяти й розуміти відмінності інших людей і культур;

- навчитися знати та мислити критично;

- навчитися діяти, використовувати знання, співпрацювати, бути творчим;

- навчитися досягти інтелектуальної, професійної, соціальної й духовної ідентичності [2].

Цей підхід розкриває важливість освіти з погляду розвитку особистості та суспільства, а також взаємозв'язок між індивідуальними, соціальними та людськими цілями освіти й навчання. Однак те, що здавалося незаперечним на етапі формулювання загальних припущень, виявляється набагато складнішим і суперечливішим на етапі реалізації. Прийнята в 1999 р. Болонська декларація ініціювала процеси трансформації освітніх систем у країнах-членах Європейського Союзу, які сприяють реалізації пріоритетної мети, яка полягає у підтримці мобільності студентів і викладачів у Європі, але в той же час здійснюють надмірне узгодження національних систем і надмірні формалістичні процедури щодо університетів. Умови реалізації вимог Болонського процесу в Польщі, тобто глибоко вкорінені неформальні установи та фрінансові обмеження, означають, що постійна присутність терміну "якість освіти" в житті університету (в дискусіях і документах) не тягне за собою помітного поліпшення навчального процесу й наслідків виховання.

Якість освіти є результатом взаємодії багатьох взаємопов'язаних факторів, що містяться в самій освітній системі та всій соціальній системі. Змінні, що визначають якість освіти, які в основному можна розглядати як внутрішні змінні, - це науково-педагогічні кадри, адміністрація університету та його матеріальна база. Однак ці умови можна лише незначною мірою віднести до логіки внутрішньої традиції та змін університету, якість людських і матеріальних ресурсів університету визначається політичними, соціальними й економічними умовами, у яких працюють заклади вищої освіти. Теперішня полі- 
тика, фрінансові умови, а також переконання, які формують центри формування думки щодо освітніх пріоритетів, цілей освіти та якості вищої освіти, впливають на якість освіти, через вплив на навчальні програми, і насамперед на вибір і мотивацію викладачів і студентів. Для забезпечення високої якості освіти повинні створюватися умови для розвитку всеосяжної, не лише вузько усвідомленої, економічної мотивації до навчання та умов, у якій педагогічна робота науково-педагогічного працівника впливатиме на його оцінку не менше, ніж наукова робота. Якість освіти - незалежно від усіх інших факторів - це те, що виникає при взаємодії студента та викладача, і висока якість можлива лише тоді, коли обидві сторони навчального процесу характеризуються високою відданістю й довірою.

Аналізу якості освіти сприяє модель трьох вимірів якості, запропонована 1993 р., - яка розрізняє основні попередні умови (попереднє використання), змінні, що характеризують сам процес і змінні, що характеризують результати навчання (продукт).

1. Основними передумовами є рівень фрінансових витрат, кількість студентів на одного викладача, компетентності та відданість академічного персоналу, інтелектуальний рівень і мотивація студентів.

2. Змінні, що характеризують сам процес викладання та навчання, - це насамперед кількість студентських груп, кількість годин навчання при безпосередній участі викладача й кількість годин самостійної роботи студента.

3. "Продукт", тобто вплив процесу навчання, варто оцінювати на основі інтелектуального та соціального розвитку студента. Через труднощі безпосередньо виміряти цей розвиток, ми використовуємо такі заходи, як ступінь наукового рівня, а також рівень професійної активності та рівня безробіття людей із вищою освітою [3].

Модель показує взаємозалежність умов, що формують процес навчання та його результати. Результати навчання безпосередньо залежать від кількості студентських груп і кількості годин для навчання, а також відданості й мотивації обох сторін навчального процесу, які у свою чергу, залежать насамперед від рівня та способу фрінансування, а також престижу університетів і вищої освіти.

В епоху глобалізації зростає напруга між традиційним розумінням університету як закладу, корінням якого $€$ наявність історії та національної традиції - установи, у якій науково-педагогічний колектив відіграє домінуючу роль, у якій шукається достовірність і основні цивілізаційні цінності, які формуються автономно із прагненням перетворити університет на інструмент зростання політичної конкуренції. Втрата традиційного інституційного становища й унікальності університету супроводжується скороченням державних коштів на вищу освіту. Парадоксально, але в епоху, у якій ми говоримо про економіку засновану на знаннях, і в якій вища освіта визнається все більш важливим фрактором економічної конкуренції між країнами, зменшується воля та здатність держав фінансувати вищу освіту. У змаганні за державні кошти вища освіта програє іншим сорерам соціальних потреб, але й інтересам: насамперед із охорони здоров'я та пенсійного забезпечення.

Університети повинні дотримуватися ринкової логіки й отримувати ринкові джерела фінансової потужності. У європейській вищій освіті, яка традиційно базується на державних коштах, усе частіше приймаються припущення американської моделі[4]. Тиск зміни фрінансових пріоритетів і зміни положення університету можна розглядати як вплив глобальної тенденції, наслідком якої є зміни у фріскальній і грошово-кредитній політиці, що призводять до дій, які сприяють глобальним фінансовим інтересам за рахунок працівників і споживачів. Зміни у світовій системі вищої освіти є частиною змін, що відбуваються у співвідношенні сил та інтересів у світовій економіці.

Тому зміни в системі фонансування вищої освіти в Польщі варто розглядати в контексті взаємозв'язку між освітою та глобалізацією, і це, у свою чергу, із погляду змін, які глобалізація внесла до економічної політики національних держав.

Проблеми у сфері фінансування, із якими стикається польська вища освіта, схожі на проблеми, які також зачіпають найбагатші країни протягом принаймні трьох десятиліть. Однак у Польщі виникли додаткові труднощі в період, коли відбувся головний кількісний розвиток вищої освіти в Польщі. На Заході швидкий розвиток відбувся в роки післявоєнного економічного зростання та політики добробуту. 3 іншого боку, у Польщі кількісне зростання відбулося під час політичних перетворень, коли 3 одного боку був великий попит структур на державні кошти, а з іншого - нагальна потреба зменшити податкові навантаження та збалансувати державні фрінанси. Приватизація та комерціалізація означали, що вища освіта може швидко розвиватися без створення підвищеного попиту на кошти з державного бюджету. Тим часом американську модель дедалі більше критикують, що вона не відповідає потребам інноваційної економіки та посилює тенденції проти законності [4].

Процес підвищення якості освіти не може відриватися від системи фінансування освіти. Якість освіти залежить від системи фінансування не лише тому, що система $€$ джерелом ресурсів, а й тому, що вона створює стимули як для студентів, так і для викладачів. Проблеми у сфері фрінансування вищої освіти Польщі особливі через те, що швидкий кількісний розвиток вищої освіти відбувся в період глибоких політичних перетворень у Польщі. Це створило можливість запускати нові приватні джерела фрінансування, але водночас означало обмеження державного фінансування в умовах безпрецедентного збільшення кількості студентів. Із погляду стану державних фінансів, приватизація та комерціалізація вищої освіти створила зручну ситуацію, обмеживши, а точніше усунувши тиск академічної громади щодо збільшення витрат на оплату праці науково-педагогічних працівників. 3 іншого боку, викладачі спочатку використовували можливості, що відкривали розвиток приватної вищої освіти, але незабаром опинилися в новій ситуації, несприятливій як з економічного, так і з погляду престижності.

За останні 10 років система освіти в Польщі розвивається найбільш динамічно порівняно з іншими країнами Європи. Кількість закладів вищої освіти збільшилася вчетверо, у той час як кількість студентів зросла уп'ятеро. Щороку близько півмільйона молодих людей починають здобувати освіту в університетах і коледжах. Приєднавшись до Болонського процесу в 1999 р., польські університети пропонують високий рівень навчання і $€$ невід'ємною частиною європейської вищої освіти. Усі провідні університети пропонують програми англійською, включаючи медицину, технічні, гуманітарні науки, бізнес і фінанси [5].

У процесі трансформації системи вищої освіти Польщі, а також дбаючи про якість вищої освіти, у січні 2002 р. у Польщі створено Державну акредитаційну комісію (Państwowa Komisja Akredytacyjna), яка охоплює 
цивільну освіту та всю вищу освіту [6]. Компетенція комісії передбачає оцінку якості навчання як у державних, так і в приватних закладах освіти.

Польська акредитаційна комісія вважає своїм обов'язком всебічне співробітництво й діалог з усіма зацікавленими сторонами у процесі освіти, виконуючи власну програму й інституційну оцінку, а також надаючи висновки за заявками на створення нових закладів вищої освіти, розширення дозволів на встановлення непублічних інститутів і розв'язання питання про те, які освітні програми необхідно створювати в закладах вищої освіти (ENQA full members). Етичну поведінку членів та експертів Польської акредитаційної комісії регулює офріційний Кодекс етики (2009). Члени й експерти організації підписують зобов'язання, обіцяючи сумлінно виконувати обов'язки члена (експерта) Польського Комітету з акредитації, керуючись у своїй професійній діяльності принципами гідності, честі та чесності, піклування про добре ім'я Польської акредитаційної комісії й дотримуватися правил Кодексу етики ПАК і професійної етики. У своїй професійній діяльності експерти повинні виконувати свої обов'язки, дотримуючись правил поваги прав і гідності осіб, із якими вони працюють, стандартів і звичаїв Польщі й інших європейських країн, а також принципів тактовної поведінки. Експерти мають також дотримуватися таких принципів: верховенства закону і справедливості; неупередженості та незалежності; відкритості до діалогу й роздумів; прозорості та підзвітності. Експерти зобов'язані ретельно готуватися до кожної справи, ґрунтовно ознайомлюватись із необхідними документами та матеріалами справи. Експерти не мають права приймати коштів від університетів, які вони акредитують або інші матеріальні винагороди за виконання своїх функцій. Також не мають права брати на себе роль консультанта або експерта в питаннях Польської акредитаційної комісії без згоди компетентних органів і не можуть поширювати інформацію, у тому числі зміст документів, про діяльність експертів (Polska Komisja Akredytacyjna).

Польська акредитаційна комісія (Polska Komisja Akredytacyjna) $€$ незалежним колегіальним органом управління вищою освітою, яка має на меті поліпшення якості освіти. Вона утворюється міністром науки та вищої освіти із кандидатів, запропонованих Радою Конференції ректорів закладів вищої освіти Польщі, Конференції ректорів польських професійних навчальних закладів Польщі, Парламентом студентів Республіки Польща, сенатами університетів і національних наукових товариств та організацією роботодавців. До повноважень Комісії належить надання міністрові науки і вищої освіти думок, відгуків і висновків, що стосуються утворення ЗВО або його організаційного підрозділу, дозволів щодо навчальних студій у певному напрямі на тому чи іншому рівні освіти; програмної та інституційної оцінки, у тому числі педагогічної освіти й ін. [1].

Отже, бачимо, що експертна діяльність у Польщі спрямована передусім на забезпечення акредитації навчальних закладів експертами, які залучаються до вказаного виду роботи з-поміж досвідчених освітян і не проходять спеціальної професійної підготовки, а керуються у своїй діяльності регламентованими правилами, продиктованими етичним кодексом. Головним обов'язком члена (експерта) Польської акредитаційної комісії $€$ турбота про високий рівень і якість вищої освіти у Польщі.

Після підписання в 1999 р. Болонської декларації, Польща взяла на себе зобов'язання сприяти європейському співробітництву у сфері якості вищої освіти. Можна вважати, що якість освіти є прийнятною для університетів, студентів, роботодавців, центральних органів влади й інших зацікавлених сторін освітнього процесу. Наприклад, у випадку центральних органів влади якість освіти може виражатися у вигляді максимізації показників людей із вищою освітою. Для університету важливим показником якості $€$ кількість випускників, які після закінчення навчання вдало влаштувалися на роботу за професійним спрямуванням. Студенти вбачають якість освіти, в основному від професійної компетентності викладацького складу, матеріально-технічного забезпечення, доступ до бібліотек, а також інших інформаційних ресурсів, а роботодавець очікує, що випускники мають відповідну кваліфікацію.

Висновки. Входження України до Болонського процесу - це планомірний інтеграційний процес системи вищої освіти до світового та європейського освітньо-наукового простору. Сучасні глобалізаційні процеси, що зумовлюють до виконання робіт з адаптації основних тенденцій Болонського процесу й досі викликають суперечки в колі науково-педагогічних працівників і студентів. Для виконання зобов'язань Болонської декларації потрібно досить розумно та доречно вивчити і перейняти досвід європейських країн, які вже раніше стали на цей шлях. Саме такою країною $є$ Польща. Маючи тривалу історію розвитку системи забезпечення якості вищої освіти, Польща має хороші показники в Європі та світі. Зваженість і прагматизм у виконанні основних положень Болонського процесу свідчать про те, що Польща йде правильним шляхом і Україна могла б запозичити її досвід.

Виходячи з аналізу наукових джерел можна стверджувати, що труднощі, які Польща мала на шляху інтеграції до європейського освітньо-наукового простору майже подолані. Обмін досвідом Польщі допоміг би Україні безболісно і швидко наблизитися до рівня європейських країн.

\section{Список використаних джерел}

1. Ustawa Prawo o szkolnictwie $w^{\wedge}$ szym z dnia 27 lipca 2005 r. Mode of access: http://www. nauka.gov.pl/szkolnictwo-wyzsze/reforma-szkolnictwawyzszego/tekst-ujednolicony-prawo- o-szkolnictwie-wyzszym.

2. Cele edukacyjne w tym raporcie oraz w innych dokumentach Komisji Europejskiej i UNESCO omawia D. Dziewulak, Szkolnictwo wyższe w świetle raportów edukacyjnych, Studia BAS 2013/3.

3. G. Gibbs, Dimensions of Quality, The Higher Education Academy 2010, s. $14-38$.

4. Tymczasem model amerykański jest coraz częściej krytykowany jako nieodpowiadający po-trzebom innowacyjnej gospodarki i umacniajacy tendencje antyegalitarne. Zob. R. Geiger, D. Heller, Financial trends in higher education: The United States, Educational Studies 2012/3;

5. Навчання за кордоном. Система освіти Польщі [Електронний ресурс]. - Режим доступу : http://premiumstudy.com.ua

6. Система освіти в Польщі - Болонська система в Польщі [Електронний ресурс]. - Режим доступу : http://www.osvitapol.info.

\section{References}

1. The Act on Education in the Act of July 27, 2005 Mode of access: http: // www.science.gov.pl/szkolnictwo-wyzsze/reforma-szkolnictwa-wyzkiego/tekstujednolicony-prawo- about-higher-education.

2. Educational goals in this report and in other documents of the European Commission and UNESCO are discussed by D. Dziewulak, Higher education in the light of educational reports, Studies BAS 2013/3.

3. G. Gibbs, Dimensions of Quality, The Higher Education Academy 2010, pp. 14-38.

4. Meanwhile, the American model is increasingly being criticized as not responding to the needs of an innovative economy and reinforcing anti-legal tendencies. See. R. Geiger, D. Heller, Financial trends in higher education: The United States, Educational Studies 2012/3.

5. Study abroad. Poland's education system [online resource]. - Access mode: http://premiumstudy.com.ua

6. Education System in Poland - Bologna System in Poland [Electronic resource]. - Access mode: http://www.osvitapol.info. 
O. Derkach, postgraduate student

Taras Shevchenko National University of Kyiv, Kyiv, Ukraine

\section{QUALITY OF HIGHER EDUCATION IN POLAND IN THE TRANSFORMATION OF EDUCATION POLICY}

The systematic changes in higher education institutions in Poland over the past two decades are analyzed. The classical idea of spontaneous social development and the hypothesis of interaction between formal and informal institutions, developed on the basis of a new institutional educational policy, was adopted as a methodological basis for analyzing and evaluating the transformation of Polish higher education. Transformations in Polish higher education are part of a more general shift in the role of universities - changes that can limit the independence of research and make it an instrument of dominant social, political and economic forces.

The article states that the process of improving the quality of education cannot be detached from the system of financing education. The quality of education depends on the funding system not only because it is a source of resources, but also because it creates incentives for both students and teachers. The problems in the field of financing higher education in Poland are special because the rapid quantitative development of higher education occurred during a period of deep political transformation in Poland.

The activities of the State Accreditation Commission of Poland are analyzed, its main competences are highlighted. The Polish Accreditation Commission (Polska Komisja Akredytacyjna) is an independent collegiate body of higher education management aimed at improving the quality of education. It is formed by the Minister of Science and Higher Education from among the candidates proposed by the Council of the Conference of Rectors of Higher Education Institutions of Poland, the Conference of Rectors of Polish Professional Educational Institutions of Poland, the Parliament of Students of the Republic of Poland, the Senates of universities and national scientific societies and the organization of employers. The powers of the Commission include providing the Minister of Science and Higher Education with opinions, feedback and conclusions regarding the establishment of the HEl or its organizational unit, permits to study studies in a particular direction at one or another level of education; program and institutional assessment, including pedagogical education. The impact of financing higher education institutions to ensure the quality of higher education is partly considered in the article.

Keywords: higher education, quality of education, transformation, financing, the State Accreditation Commission.

УдК 378.2

DOI: https://doi.org/10.17721/2415-3699.2020.12.04

М. Жиленко, канд. пед. наук, доц. Київський національний університет імені Тараса Шевченка, Київ

\section{УМОВИ ЕФЕКТИВНОГО ДЕЛЕГУВАННЯ ПОВНОВАЖЕНЬ МЕНЕДЖЕРОМ ЗАКЛАДУ ВИЩОЇ ОСВІТИ}

Досліджено рівень готовності менеджера ЗВО до делегування своїх повноважень і узагальнено досвід такої діяльності. У ході вивчення діяльності проректорів, начальників відділів, деканів факультетів, директорів інститутів, навчально-наукових центрів закладу вищої освіти з'ясовано, що керівник (менеджер), як суб'єкт управління, повинен вміти проаналізувати ситуацію, спрогнозувати стратегію, спланувати тактику для досягнення визначених цілей і організувати оперативне управління з їхньої реалізації. Проте більшість із досліджуваних підходять до розв'язання цієї проблеми на рівні буденної свідомості, не завжди розуміють, що управління - це насамперед уміння організувати роботу в команді. Ефективність управлінської праці керівника в закладі вищої освіти здебільшого залежить від особистісних характеристик керівника, але обов'язковим компонентом їі продуктивності є компетентності, які не можуть бути сформовані без спещіальних знань. Порядок обрання та призначення на посаду наявності таких знань не передбачає. Менеджер закладу освіти практично не може впливати на рівень передбачуваності завдань, які мають зовнішню природу, у той час як професійна організація й упорядкування структури внутрішньої діяльності дає значні переваги. Одним із напрямів оптимізації структури внутрішньої діяльності управлінця та підвищення ії ефективності є готовність і уміння делегувати свої повноваження. Це в межах добре спланованої роботи дає можливість керівникові отримати найбільший резерв часу. Аналіз практики діяльності успішних менеджерів і наукової літератури з означеної проблеми дозволив сформулювати рекомендації керівникам для успішного делегування повноважень, які передбачають використання певних принципів делегування, чітке розуміння видів і обсягу діяльності, робіт, які можна делегувати; розуміння порядку і процедури визначення цілей і постановки завдань; урахування професійних можливостей персоналу. Доведено, що важливою умовою ефективного делегування є оволодіння керівником логікою формулювання і процедурою постановки розумних цілей, що має забезпечити напружений ритм для кожного працівника з урахуванням цілей діяльності, особистісних і професійних можливостей.

Ключові слова: структура внутрішньої діяльності, делегування, принципи делегування, концепція смарт, розумні цілі.

Постановка проблеми. В умовах модернізації системи вищої освіти в Україні, нормативно-законодавча база передбачає демократичну процедуру для зайняття посади керівника в закладах вищої освіти. У статті 42 Закону України "Про вищу освіту" сказано - обрання, призначення та звільнення з посади керівника закладу вищої освіти передбачає, що кандидат повинен вільно володіти державною мовою, мати вчене звання та науковий ступінь, стаж роботи на посадах науково-педагогічних працівників не менше як 10 років тощо. Для кандидата не передбачено вимог щодо наявності спеціальних знань з освітнього менеджменту [4], хоча в цьому ж Законі, у розділі 7 ст. 34, визначаються повноваження керівника закладу вищої освіти (пункт 3): організовує діяльність закладу; вирішує питання фінансово-господарської діяльності, затверджує його структуру і штатний розпис; видає накази й розпорядження, дає обов'язкові для виконання всіма учасниками освітнього процесу і структурними підрозділами доручення тощо, здійснює інші передбачені статутом повноваження [1]

Якщо порівняти вимоги до претендента і зміст його повноважень, стає очевидним, що для ефективного здійснення місії керівникові потрібен ряд компетентностей із планування і організації, якими, виконуючи обов'язки на посадах науково-педагогічних працівників, навіть 10 років, маючи науковий ступінь і вчене звання, відповідаючи іншим вимогам ст. 42 Закону, кандидат може не володіти. I тому, ураховуючи зміст повноважень керівника, дуже важливою компетентністю для нього $€$ здатність делегувати свої повноваження. Зараз у системі освіти працюють випускники освітніх програм з управління закладами освіти, які володіють необхідними компетентностям та програмними результатами навчання згідно зі стандартом вищої освіти, із яких керівник може створити команду і в такий спосіб підвищити рівень менеджменту в ЗВО [7]. Вивчення рівня готовності менеджера ЗВО до 